\title{
The Impact Analysis of Features and Perceived Quality on Consumer Satisfaction of Samsung Mobile Phones in Makassar City
}

\author{
Dadah Muliansyah $^{1}$, Yoyok Cahyono ${ }^{2}$, Ade Onny Siagian ${ }^{3}$ \\ ${ }^{1}$ Universitas Tangerang Raya (UNTARA), Indonesia \\ ${ }^{2}$ Universitas Pramita Indonesia (UNPRI), Indonesia \\ ${ }^{3}$ Universitas Bina Sarana Informatika, Indonesia \\ dachmuliansyah@gmail.com,yoyok.unpri@gmail.com,ade.aoy@bsi.ac.id
}

\section{Abstract}

This study aims to determine whether Features and Perceived quality affect Samsung Mobile Consumer satisfaction in Makassar City. The population in this study are consumers who use Samsung mobile phones in Makassar City. Based on the research results, the regression equation is obtained as follows $Y=5.308+0.389 \mathrm{X} 1+$ 0.321 X2. Based on statistical data analysis, each indicator in this study is valid and the variables are reliable. In testing the classical assumptions, the regression model is multicolonierity free, heteroscedasticity does not occur, and is normally distributed. The results of hypothesis testing, namely the T test results prove that all independent variables, namely Features and Perceived Quality, have a positive effect on Consumer satisfaction on Samsung Mobile Phones in Makassar City and the F test shows that features and perceived quality simultaneously have a significant effect on Consumer satisfaction, with a calculated $F$ value of 13.976 with a significance of $0.000<0.05$. The coefficient of determination $R$ square is 0.536 . This means that $53.6 \%$ of consumer satisfaction is influenced by the features and perceived quality variables, the remaining $45.3 \%$ is influenced by other variables. The coefficient of determination for $R$ square is 0.536 . This means that $53.6 \%$ of consumer satisfaction is influenced by the features and perceived quality variables, the remaining $45.3 \%$ is influenced by other variables. The coefficient of determination for $R$ square is 0.536 . This means that $53.6 \%$ of consumer satisfaction is influenced by the features variable and perceived quality, the remaining $45.3 \%$ is influenced by other variables.

Keywords

features, perceived quality reliability, assurance; customer satisfaction

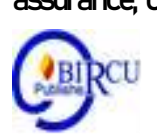

\section{Introduction}

Samsung, the largest electronic device maker in the world, is the largest conglomerate in South Korea and is headquartered in Seocho Town in Seoul, South Korea. The Samsung company also always strives to create quality products and have more value than competing products, for example the Samsung Galaxy A4 which uses the latest Marsmellow Android OS which offers many attractive applications and features aimed at increasing the satisfaction received by consumers for a product that is used with provide better deals and services, and companies will be able to improve consumer satisfaction. Consumer satisfaction is a very determining factor in increasing consumer loyalty, on the other hand, customer disappointment in providing service can lead to company destruction in the future. The 
creation of customer satisfaction can provide several benefits, including harmonious relationship between the company and consumers, providing a good basis for repurchasing and creating customer loyalty and providing word of mouth recommendations that are beneficial for the company (Siagian, 2019)..

According to (Hasanuddin, 2019), Consumer satisfaction is the level of a person's happy feelings after comparing the performance or results he feels with his expectations. In general, the expectations of customers are estimates of customer beliefs about what they will receive when they buy or consume a product. With good product quality in a product, it will create satisfaction for users. After users are satisfied with the products or services they receive, users will compare the services provided.

According to (K. Kotler, 2014), product quality, namely the product's ability to perform its function, this includes the time of use of the product, reliability, ease of use and repair, and other values. A product is said to be of high quality if it meets the needs and desires of consumers Features will affect the level of consumer satisfaction if post their purchase feels that the features found on their Samsung mobile phone are as expected (good / unique feature) so the purchase will continue and the user will be satisfied (P. Kotler \& Amstrong, 2008). Features are additional characteristics that exist in a product.

Research on Features based on Features found that the relationship between Features and Consumer satisfaction has a positive effect. Research conducted by (D. J. Kim, 2012) dan (Gofur, 2019) al (2015) states that features have a positive and significant effect on consumer satisfaction. Because a product with better features (good / unique feature) will affect consumer satisfaction.

Perceived quality has an important role in creating consumer satisfaction. With the increasingly fierce competition for similar products, Perceived quality can play a role in presenting a brand in the minds of consumers in accordance with the wishes of the brand and being able to distinguish from its competing brands Perceived quality is also where customer perceptions of the whole quality is related to what the customer expects, it will indirectly be able to encourage purchasing decisions and create loyalty to the product.

Research on consumer satisfaction based on perceived quality found that the relationship between perceived quality and consumer satisfaction had a positive effect. Research conducted (El-Adly, 2019) stated that Consumer satisfaction has a positive effect on perceived quality. Perceved quality is strong and in line with consumer desires, consumers will feel satisfied.

\subsection{Formulation of the Problem}

1. Do Features affect Mobile Consumer satisfaction Samsung in Makassar City

2. Does Perceived Quality affect Consumer Satisfaction Samsung mobile phones in Makassar city

3. Do Features and Perceived quality have a simultaneous effect on Consumer Satisfaction of Samsung Mobile in Makassar City 


\section{Review of Literatures}

\subsection{Consumer Satisfaction}

Consumer satisfaction is a condition that consumers feel after they experience a performance or result that has met various expectations in accordance with their expectations. If consumers feel satisfied with a product, of course, these consumers will always use or consume the product continuously. According to (Oliver, 2014), Consumer satisfaction is the level of a person's happy feelings after comparing the performance or results he feels with his expectations. In general, the expectations of customers are estimates of customer beliefs about what they will receive when they buy or consume a product. According to (Oliver, 2014), Consumer satisfaction demand can be determined based on three main factors that must be considered by a company, namely product quality, emotionality and price.

Consumer behavior is very dynamic and tends to be adaptive, quickly adjust to the demand of the people who always need the public transport. Their demand is complex so that the government should create a good strategy for transport service quality. They need to be managed by the best managers in order to adapt to the users' expectation. In addition, a continuous performance valuation should also be done in order to narrow the gap between the expected and perceived service users. They should know the consumer behavior well, with a full understanding of the public habits. They even have to understand the people's movement and activities well. By doing so, the needs of consumers can be fulfilled. (Sukesi and Yunus, 2018)

\subsection{Product Quality}

Product quality is an important thing in determining the selection of a consumer product. The product on offer must be a product that has really been tested well regarding its quality because for consumers what is prioritized is the quality of the product itself. According to (Institute of Leadership \& Manageme, 2020) said product quality is the product's ability to perform its function, this includes the useful life of the product, reliability of ease of use and repair, and other values.

(Amstrong, 2010) Theory that the dimensions of product quality are divided into eight, namely performance, features, reliability, conformance, durability. Serviceability, aesthetic. image or reputation (perceived quality). And what is used in this study are features, and perceived quality. The development of business organizations depends on the quality of the products they produce. The better the product produced and useful, the more consumers will enjoy it, especially to meet their daily needs. The quality of products that are in great demand by consumers can be seen from several factors including packaging, price, quality, and benefits obtained by consumers. (Romdonny et al, 2019)

\subsection{Features}

In theory, product quality features are one of the elements of product quality. Features can be said as a secondary aspect of a product. Features are identical with something unique, distinctive, and special that are not owned by other products (Saleh \& Siagian, 2020). According to (Susanti, 2017) features are additional characteristics that are designed to increase consumer interest in the product or enhance product functionality.

According to (Amstrong, 2010) Features are characteristics or features that an object may or may not have. Various products that are similar can be seen differently by consumers from the comparison of the features in them, namely the comparison of features completeness, sophistication of features or features that are highlighted from one feature in a product compared to other products. 
According to (Arianty, 2015) said that product features are measured through three indicators, namely diversity of features, features according to expectations and features that haveadvantages.

\subsection{Perceived Quality}

Perceived quality is the customer's perception of the overall quality or superiority of a product or service in relation to what the customer expects. Because perceived quality is the perception of the customer, the perceived quality cannot be determined objectively (Siagian et al., 2020). According to (H. Kim \& Niehm, 2009) argued that perceived quality is the consumer's perception of all the quality or excellence of a product in relation to the intended purpose. Referring to the opinion of Garvin 1999 (Snoj et al., 2004). The dimensions of Percived Quality are divided into 3, namely Resilience, Reliability and Crateristics.

\section{Research Methods}

\subsection{Data Analysis Technique}

The method used in this research is a survey method, in which the researcher directly Observes and makes data decisions directly in the city of Makassar. According to (Basuki \& Nano, 2017), the formula that can be used as a calculation of multiple linear regression analysis is as follows:

$$
\mathrm{Y}=\mathrm{a}+\mathrm{b} 1 \mathrm{X} 1+\mathrm{b} 2 \mathrm{X} 2+\mathrm{e}
$$

Information:

$\mathrm{Y}=$ Consumer satisfaction (dependent) $\mathrm{a}=$ constant

$\mathrm{X} 1=$ features (independent)

$\mathrm{X} 2=$ perceived quality (independent) $\mathrm{b} 1=$ regression coefficient $\mathrm{X} 1$

$\mathrm{b} 2$ = regression coefficient $\mathrm{X} 2$

$\mathrm{e}=$ Error

\subsection{Population and Sample}

The populations used in this study were Samsung handpond users in the city of Makassar. During the last 6 months, the sample in this study used the accidental sampling technique, in which the researcher selects which members of the population who accidentally meet the researcher are considered to be able to provide the necessary information. Determination of the number of samples to be used in this study will use a formula (quantitative, qualitative, and $R \& D, 2016$ ). as stated below

$$
\begin{aligned}
\mathrm{n} & =(5 \times \text { number of indicators used }) \\
& =5 \times 9 \text { indicators } \\
& =45 \text { rounded to } 50 \text { samples }
\end{aligned}
$$

Based on the above calculations, the minimum sample used in this study was 50 respondents. 


\section{Result and Discussion}

Multiple linear regression analysis is used in this study with the aim of proving the hypothesis regarding the influence of the Features and Perceived quality variables partially or simultaneously on customer satisfaction.

Table 1. Results of Multiple Linear Regression Analysis

Coefficientsa

\begin{tabular}{|c|c|c|c|c|c|}
\hline \multirow{2}{*}{$\begin{array}{l}\text { Mod } \\
\text { el }\end{array}$} & \multicolumn{2}{|c|}{$\begin{array}{l}\text { Unstandardized } \\
\text { Coefficients }\end{array}$} & \multirow{2}{*}{$\begin{array}{c}\begin{array}{c}\text { Standardized } \\
\text { Coefficients }\end{array} \\
\text { Beta }\end{array}$} & \multirow[t]{2}{*}{$\mathrm{t}$} & \multirow[t]{2}{*}{ Sig. } \\
\hline & $\mathrm{B}$ & $\begin{array}{l}\text { Std. } \\
\text { Error }\end{array}$ & & & \\
\hline (Constant) & 5,308 & 3,471 & & 1,529 & 133 \\
\hline features & .389 & .094 & .492 & 4,159 & .000 \\
\hline $\begin{array}{l}\text { perceived } \\
\text { quality }\end{array}$ & .321 & .141 & .269 & 2,272 & .028 \\
\hline
\end{tabular}

\subsection{T Test (Partial Hypothesis Testing)}

To test the significance of the regression model for each variable partially it can be obtained by using the $t$ test. The following will explain the partial testing of each variable.

a. Variable Features

The test results obtained that the $t$ value for the features variable shows a t value of 4.159 with a significance value of $0.000<0.05$. With a significance value below 0.05 , it shows that features have a positive effect on consumer satisfaction.

b. Perceived Quality Variable

The test results obtained by the $t$ value for the perceived quality variable showed a value of $t=2.272$ with a significance value of $0.028<0.05$. With a significance value below 0.05 , it shows that perceived quality has a significant effect on consumer satisfaction on Hendpond Samsung in Makassar city

\subsection{F Test (Simultaneous Hypothesis Testing)}

Table 2. Simultaneous test (Test F)

ANOVAb

\begin{tabular}{|c|c|c|c|c|c|c|}
\hline Model & $\begin{array}{l}\text { Sum of } \\
\text { Squares }\end{array}$ & df & $\begin{array}{l}\text { Mean } \\
\text { Square }\end{array}$ & $\mathrm{F}$ & Sig. & \\
\hline 1 & Regression & 69,364 & 2 & 34,682 & \multirow{3}{*}{$\begin{array}{l}13,97 \\
6\end{array}$} & \multirow{3}{*}{$\begin{array}{l}.000 \\
\mathrm{a}\end{array}$} \\
\hline & Residual & 116,636 & 47 & 2,482 & & \\
\hline & Total & 186,000 & 49 & & & \\
\hline
\end{tabular}

$c$. Predictors: (Constant), perceived quality, features

$d$. Dependent Variable: consumer

In the table above, testing the effect of the independent variable simultaneously on the dependent variable was carried out using the $\mathrm{F}$ test. The results of statistical calculations showed the value of $\mathrm{F}$ count $=13.976$ with a significance of $0.000<0.05$. With a significance value below 0.05, it shows that the Features and Perceived Quality variables have a simultaneous effect on consumer satisfaction on Hendpond Samsung in Makassar City 


\section{Conclusion}

From the results of research on the effect of features and perceived quality on consumer satisfaction, then the following conclusions can be drawn:

1. The results showed that the features variable (X1) has a regression coefficient of 0.389 on consumer satisfaction ( $\mathrm{Y}$ ) and the $\mathrm{t}$ value is 4.159 with a significance level of 0.000 $<0.05$. This means that features (X1) have a positive effect on consumer satisfaction (Y) on Samsung mobile phones in the city of Makassar. Thus the first hypothesis which states that features (X1) have a positive effect on (Y) consumer satisfaction on Samsung mobile phones in Makassar city can be accepted.

2. The results showed that the variable perceived quality (X1) has a regression coefficient of 0.321 on consumer satisfaction (Y) and the $t$ value is 2.272 with a significance level of $0.028<0.05$. This means that perceived quality (X2) has a positive effect on consumer satisfaction (Y) on Samsung mobile phones in Makassar city. Thus, the second hypothesis which states that perceived quality (X2) has a positive effect on (Y) consumer satisfaction on Samsung mobile phones in the city of Makassar can be accepted.

3. Features and simultaneous perceived quality has a positive effect on consumer satisfaction. This is evidenced by the test results obtained by the calculated $F$ value of 13.976 with a significance of $0.000<0.05$. This means that features and perceived quality simultaneously have a positive effect on consumer satisfaction (Y) on Samsung mobile phones in Makassar city. Thus, the third hypothesis which states that features and perceived quality have a positive effect simultaneously on (Y) consumer satisfaction on Samsung mobile phones in the city of Makassar can be accepted.

4. The result of regression calculation shows that the coefficient of determination ( $R$ square) is 0.547 . This means that $54.7 \%$, Consumer satisfaction is influenced by Features and Perceived quality, while the rest is $45.3 \%$. Consumer satisfaction is influenced by other variables not examined in this study.

\section{References}

Amstrong, K. (2010). Pengertian kualitas produk. Jackson R.S. Weenas - Kualitas Produk, Harga, Promosi Dan Kualitas Pelayanan Pengaruhnya Terhadap Keputusan Pembelian Spring Bed Comforta.

Arianty, N. (2015). Pengaruh Kualitas Pelayanan Dan Kualitas Produk Terhadap Kepuasan Konsumen Handphone Samsung. Jurnal Ilmiah Manajemen Dan Bisnis.

Basuki, A. T., \& Nano, P. (2017). Analisis Regresi Dalam Penelitian Ekonomi dan Bisnis. In PT Rajagrafindo Persada, Depok.

Cahyono, Y., Purwanto, A., Sukanta, F. N. A., Fitriaty, H. W., Sihotang, M., \& Sugianto, A. (2020). Impact Of Service Quality, University Image And Students Satisfaction Towards Studentloyalty: Evidence From Indonesian Private Universities. Journal of Critical Reviews, 7(19), 3916-3924.

El-Adly, M. I. (2019). Modelling the relationship between hotel perceived value, customer satisfaction, and customer loyalty. Journal of Retailing and Consumer Services. https://doi.org/10.1016/j.jretconser.2018.07.007

Gofur, A. (2019). Pengaruh Kualitas Pelayanan Dan Harga Terhadap Kepuasan Pelanggan. Jurnal Riset Manajemen Dan Bisnis (JRMB) Fakultas Ekonomi UNIAT. https://doi.org/10.36226/jrmb.v4i1.240 
Gunartin, A. O. S., Nufus, K., Nur'aini Yusuf, H. S., Maddinsyah, A., Muchtar, A., Sari, W. I., ... \& Noryani13, H. W. A Systematic Literature Review of Education Financing Model in Indonesian School.

Hasanuddin, A. H. (2019). Pengaruh \{Kualitas\} \{Produk\}, \{Citra $\}$ Merek\} dan $\{$ Harga $\}$ \{Terhadap\} \{Kepuasan\} \{Pelanggan $\}$ dan \{Dampaknya $\}$ pada \{Minat $\{$ Beli $\}$ \{Ulang\} (\{Studi $\}$ Kasus $\}:\{$ Minuman $\}$ Kekinian $\}\{$ Dum $\}-\{$ Dum $\}$ Thai $\}\{$ Tea $\}$ di $\{$ Kota $\}$ Pontianak\}). Jurnal Manajemen Update.

Haudi, H. W., \& Cahyono, Y. (2020). Analysis of Most Influential Factors to Attract Foreign Direct Investment. Journal of Critical Reviews, 7(13), 4128-4135.

Haudi, H. W., \& Cahyono, Y. (2020). Effect Of Product Innovation and Marketing Strategy on Consumer Purchase Decisions In Indonesia's Lightweight Roof Steel Industry. Journal of Critical Reviews, 7(13), 4147-4155.

Institute of Leadership \& Manageme. (2020). Product quality. In Marketing for Managers. https://doi.org/10.4324/9780080914947-10

Kim, D. J. (2012). An investigation of the effect of online consumer trust on expectation, satisfaction, and post-expectation. Information Systems and E-Business Management. https://doi.org/10.1007/s10257-010-0136-2

Kim, H., \& Niehm, L. S. (2009). The Impact of Website Quality on Information Quality, Value, and Loyalty Intentions in Apparel Retailing. Journal of Interactive Marketing. https://doi.org/10.1016/j.intmar.2009.04.009

Kotler, K. (2014). Manajemen Pemasaran. Manajemen Pemasaran.

Kotler, P., \& Amstrong, G. (2008). Fundamentos de Marketing. In Prentice Hall.

Oliver, R. L. (2014). Satisfaction: A behavioral perspective on the consumer, Second edition. In Satisfaction: A Behavioral Perspective on the Consumer, Second Edition. https://doi.org/10.4324/9781315700892

Romdonny, J. et al. (2019). Factors Affecting Customer Loyalty in Products. Budapest International Research and Critics Institute-Journal (BIRCI-Journal). P. 337-343.

Saleh, R., \& Siagian, A. O. (2020). Sponsorship dalam Menciptakan Sikap Merek. Jurnal Bisnis Terapan. https://doi.org/10.24123/jbt.v4i1.2404

Setyawati, E., Wijoyo, H., \& Soeharmoko, N. (2020). Relational Database Management System (RDBMS).

Siagian, A. O. (2019). Pengaruh Daya Tarik Iklan Dan Penempatan Produk Terhadap Kesadaran Merek Grab di Acara Indonesian Idol 2018. Jurnal Pemasaran Kompetitif. https://doi.org/10.32493/jpkpk.v3i1.3621

Siagian, A. O., Martiwi, R., \& Indra, N. (2020). Kemajuan Pemasaran Produk Dalam Memanfaatkan Media Sosial Di Era Digital. Jurnal Pemasaran Kompetitif. https://doi.org/10.32493/jpkpk.v3i3.4497

Snoj, B., Pisnik Korda, A., \& Mumel, D. (2004). The relationships among perceived quality, perceived risk and perceived product value. Journal of Product \& Brand Management. https://doi.org/10.1108/10610420410538050

Sukesi and Yunus, E. (2018). Service Quality in Public Transport Services of the Provicial Intercity Transportation (AKDP) in East Java Indonesia. Budapest International Research and Critics Institute-Journal (BIRCI-Journal). P. 161-169.

Sunarsi, D. (2020). Implikasi Digitalisasi Umkm. Digitalisasi UMKM, 57.

Suherman, M., Wijoyo, H., \& Indrawan, I. (2020). INDUSTRY 4.0 vs SOCIETY 5.0.

Metode penelitian kuantitatif, kualitatif,dan R\&D, Alfabeta, cv. (2016).

Susanti, D. (2017). Pengaruh Kualitas Produk Terhadap Minat Konsumen Dalam Membeli Produk Tupperware Pada Perumahan Griya Tika Utama Pekanbaru. Menara Ekonomi. 
Wijoyo, H., Haudi, H., Ariyanto, A., Sunarsi, D., \& Akbar, M. F. (2020). Pelatihan Pembuatan Konten Digital Marketing Dalam Meningkatkan Kompetensi Mahasiswa (Pengabdian Kepada Masyarakat Kerjasama Antar Kampus). IKRA-ITH ABDIMAS, 3(3), 169-175.

Wijoyo, H. Problematika Hukum di Bidang Investasi dalam Era Otonomi Daerah. Jurnal Hukum Respublica, 5(2).

Wijoyo, H., \& Sunarsi, D. (2020). Manajemen internasional. CV. Insan Cendekia Mandiri.

Wijoyo, H. Digitalisasi Umkm Pasca Pandemi Covid-19 Di Riau. Prosiding Konferensi Nasional Administrasi Negara Sinagara 2020.

Wijoyo, H., Cahyono, Y., Ariyanto, A., \& Wongso, F. (2020). Digital economy dan pemasaran era new normal. Insan Cendekia Mandiri. 